\title{
Determination of Heavy Metals in Sawdust Particles, Distribution in Soil and Accumulation in Plants at Ahiaeke Timber Market in Umuahia, Nigeria
}

\author{
Ogbonna, P.C. ${ }^{1, *}$, Kalu, E.N. ${ }^{2}$ and Nwankwo, O.U. ${ }^{3}$ \\ ${ }^{1,2 \& 3}$ Department of Environmental Management and Toxicology, Michael Okpara University of Agriculture \\ Umudike, P.M.B. 7267 Umuahia, Abia State, Nigeria
}

Corresponding Author: *ogbonna_princewill@yahoo.com

\begin{abstract}
Farmers are constrained to farming on lands adjoined to sources of pollution without considering the health implications of consuming crops grown on such lands. The main route of entry of heavy metals in human body is via ingestion of food contaminated with heavy metals. Heavy metal toxicity has proven to be a major threat and there are several health risks associated with it. This, therefore, necessitated the determination of heavy metals in sawdust, distribution in soil and accumulation in plants at Ahiaeke timber market in Umuahia, Abia State. The study assessed metals (chromium [Cr], zinc [Zn], cadmium [Cd], and copper [Cu]) in sawdust particles, their distribution in soil and accumulation in plants. The highest concentration of $Z n(51.00 \pm 1.84 \mathrm{mg} / \mathrm{kg})$ and $\mathrm{Cr}(0.170 \pm 0.014 \mathrm{mg} / \mathrm{kg})$ was observed at the sawdust dump 2, $\mathrm{Cu}(8.24 \pm 0.60 \mathrm{mg} / \mathrm{kg})$ was highest at sawdust dump 1 while $C d(4.72 \pm 0.071 \mathrm{mg} / \mathrm{kg})$ was highest at sawdust dump 3. The values of the highest concentration of $\mathrm{Zn}(119.7 \pm 7.02 \mathrm{mg} / \mathrm{kg}), \mathrm{Cu}(75.85 \pm 4.80 \mathrm{mg} / \mathrm{kg})$ and $\mathrm{Cd}$ $(22.39 \pm 3.30 \mathrm{mg} / \mathrm{kg})$ in soil were observed in $0-10 \mathrm{~cm}$ depth at the distance of $20 \mathrm{~m}$. The values of $\mathrm{Zn}(119.7 \pm 7.02 \mathrm{mg} / \mathrm{kg})$ and $C d(22.39 \pm 3.30 \mathrm{mg} / \mathrm{kg})$ in soil is above the maximum permitted levels of $60 \mathrm{mg} / \mathrm{kg}(\mathrm{Zn})$ and $0.1 \mathrm{mg} / \mathrm{kg}(\mathrm{Cd})$ established by the Codex Alimentarius Commission. The highest concentration of $\mathrm{Zn}(34.70 \pm 7.05 \mathrm{mg} / \mathrm{kg}), \mathrm{Cu}(5.34 \pm 0.11 \mathrm{mg} / \mathrm{kg})$ and $\mathrm{Cd}(2.94 \pm 0.515)$ in plants was assimilated by Centrosema pubescence. The level of $C d$ in plants is well above the permissible limit $(P L) 0.3 \mathrm{mg} / \mathrm{kg}$ set by FAO/WHO for vegetables and herbs. Consumption of such contaminated C. pubescence can be a route of entry of Cd in grazing animals' vis-à-vis the people who depend on such herbivores for protein.
\end{abstract}

Keywords: Sawdust, Heavy metals, Soil, Plants, Distance, Depths

\subsection{Introduction}

The environment is continuously being contaminated by various human activities, such as industrial production, agricultural processes, and mineral exploitation, food processing, commercial, social, and domestic activities that generate contaminants like heavy metals. The release of heavy metal is of great concern all over the world since metal are non-biodegradable (Wu and Zhang, 2010) and cannot be detoxified and removed by metabolic activities once they are available in the environment. This can result to the building-up of toxic levels in terrestrial and aquatic ecosystem. Metals such as zinc $(\mathrm{Zn})$, copper $(\mathrm{Cu})$, manganese $(\mathrm{Mn})$, iron $(\mathrm{Fe})$, and nickel $(\mathrm{Ni})$ are required by living organism to support their metabolic function but are toxic when they exceed their normal threshold in soil through external addition. Non-essential metals such as lead $(\mathrm{Pb})$, chromium $(\mathrm{Cr})$, mercury $(\mathrm{Hg})$ and cadmium (Cd) are not needed for growth of living organisms (Kabata-Pendias, 2011).

Plants growing on metal contaminated soil tend to absorb metals from soil solution via the roots and translocate it to the stems and the leaves. Their (metals) chemical form in soil can strongly influence their uptake by plants (Pitchell and Anderson, 1997) through the roots (either as mobile ions present in the soil solution) (Davies, 1983) or through foliar absorption (Chapel, 1986) resulting in 
bioaccumulation of the elements in plants tissues (Amusan et al., 2005). This however, is dependent on the type of metal, plant species and plant part (Juste and Mench, 1992). The exploitation of such trees at maturity and subsequent processing at timber markets will result to release of metal in form of dust particles in the environment. The increasing demand for wood as building material, for furniture purposes, sculptural work, and in various industries vis-à-vis poor planning and ineffective implementation of budget allocation for waste collection and disposal by the Government has resulted to high volumes of sawdust waste at dumpsites in Umuahia timber market. The decomposition of the sawdust may culminate to contamination of the immediate surroundings via leaching of metals and other chemical pollutants into the soil. The concomitant effect is possible ecological imbalance and deterioration in the quality of plant products around the vicinity. Similarly, it may result to bioaccumulation of metals in plants; hence culminate to bio magnification in food chain via herbivorous animals and man that depend on such plants for food and medicine.

Heavy metal toxicity has proven to be a major threat and there are several health risks associated with it (Mathew et al., 2014) which include hyperkeratosis, loss of skin pigmentation, cancers of the skin, bladder, and lung (WHO, 2001), vomiting, diarrhea, abdominal cramps, liver and kidney damage (Plunkett, 1987), impair reproduction and abnormal development of children, nervous and immune systems, dental and skeletal fluorosis (Finkelman, 2007). Quite a number of studies on sawmilling and/or wood processing activities have been carried out in terms of the health effects of workers of the sawmills (Boateng and Amedofu, 2004; Ugheoke et al, 2006; Oke and Oyedare, 2006; Arimoro et al, 2007; Verma et al, 2007; Lasode and Balogun, 2010; Bello and Mijinyawa, 2010; Edith and Nkwocha, 2012), heavy metals in sawdust particles (Nwajei and Iwegbue, 2007; Ncube and Phiri, 2015) and soil (Ezekiel et al., 2013). Literature search show that no work has been done on metal accumulation in plants at timber market or sawmills. This study, therefore, attempted to fill this gap by investigating heavy metal distribution in soil and accumulation in plants at Ahiaeke timber market, Nigeria. The specific objectives were to identify some metals in sawdust, their distribution in soil at various depths and distances and accumulation in plant species around the timber market sawdust dumpsite.

\subsection{Methodology}

\subsection{Description of study area}

The study was carried out at the Ahiaeke timber market located at Ahiaeke in Umuahia North, Abia State, Nigeria. Ahiaeke lies on latitude $05^{\circ} 29^{\prime}$ to $05^{\circ} 42^{\prime} \mathrm{N}$ and longitude $07^{\circ} 24^{\prime}$ to $07^{\circ} 33^{\prime} \mathrm{E}$, and it is located on the low land rainforest zone of Nigeria (Keay, 1959). The area has two distinct seasons in a year which are the wet season and the dry season. The rainy season covers a period of seven months from April to October, while dry season last for four months from November to March each year with an average rainfall of $2238 \mathrm{~mm}$ per year (Ogbonna and Nzegbule, 2009). Its minimum and maximum temperature is 23 and $32{ }^{\circ} \mathrm{C}$, respectively and a relative humidity of 60-80\% (Ogbonna and Nzegbule, 2009) while the estimated terrain elevation above sea level is $155 \mathrm{~m}$. Agriculture is the major occupation of the people where over $70 \%$ of the population engages in subsistent farming and the main food crops grown are yam, maize, cassava, cocoyam, banana, plantain, palm tree and raffia palm.

\subsection{Sawdust analysis of the timber market}

A reconnaissance survey was carried out prior to sample collection at the timber market. This was to identify the location of the sawdust waste dumps and plant species commonly found at the site. Three sawdust waste dumps (1,2, and 3) were located at the Ahiaeke timber market. Sawdust particles were collected randomly from fifteen different sampling points in four cardinal points (i.e. three sampling points each at north $(\mathrm{N})$, south $(\mathrm{S})$, east $(\mathrm{E})$, west $(\mathrm{W})$, and at the centre $(\mathrm{C})$ of the dumps from each dump. Samples from each particular sawdust dumps (e.g. 15 sampling points at N, S, E, W, and C dumpsite 1) were placed (about $2 \mathrm{~kg}$ ) in large, well cleaned cellophane bags (of Abia State Environmental Protection Agency (ASEPA) and transferred to the laboratory for pre-treatment and analysis. The sawdust was sieved through $0.2 \mathrm{~mm}$ sieve, and sawdust that passed through the sieve was kept in a refrigerator prior to digestion. A $2 \mathrm{~g}$ of the sieved sawdust was weighed and digested in acid mixture prepared from $15 \mathrm{ml}$ nitric acid and $3 \mathrm{ml}$ perchloric acid. The solutions were kept on a 
hot plate at $130{ }^{\circ} \mathrm{C}$ for $2 \mathrm{hrs}$. The clear digest was slowly evaporated and on cooling, the solution was filtered and the filtrate was diluted to $25 \mathrm{ml}$ using deionized water. The concentrations of chromium $(\mathrm{Cr})$, zinc $(\mathrm{Zn})$, cadmium $(\mathrm{Cd})$, and copper $(\mathrm{Cu})$ in the digested samples were determined using flame Atomic Absorption Spectrophotometer, AAS (PG Instrument, model: Pg-500, UK)) after calibrating the equipment with different standard concentrations.

\subsection{Soil analysis of the experimental site}

Soil samples were collected randomly from eight different sampling points at 0-10, 11-20, and 21-30 $\mathrm{cm}$ soil depth with well cleaned Dutch soil auger in four cardinal points (i.e. two sampling points each at north (N), south (S), east (E) and west (W) of 20, 40, 60 and $80 \mathrm{~m}$ from the centre of the sawdust wastes dumps. The control sample was collected in a 5 year upland bush fallow about $500 \mathrm{~m}$ from the dump sites where there was no visible source of contamination. Samples from each particular soil depth (e.g., 0-10 cm at N, S, E and W) were placed in cellophane bags (about $20 \mathrm{~g}$ ), labelled well, and were transferred to the laboratory for pre-treatment and analysis. Samples from the same soil depth were bulked together to give composite samples which were homogenized and air-dried in a circulating air in the oven at $30{ }^{\circ} \mathrm{C}$ to a constant weight and passed through a $2 \mathrm{~mm}$ sieve. Subsamples from the composite samples were then digested. About $10 \mathrm{ml}$ of nitric acid was added to $2 \mathrm{~g}$ of air dried and processed soil in a $100 \mathrm{ml}$ beaker and the mixture was reacted and heated by the addition of $3 \mathrm{ml}$ of perchloric acid, allowed to stand for $15 \mathrm{~min}$. The mixture was digested by heating gently at low temperature on a hot plate and allowed to cool for 5 minutes. The digest was then filtered with Whatman No. 41 filter paper into $50 \mathrm{ml}$ standard flask. The suspension was filtered into $50 \mathrm{ml}$ standard flask and diluted with de-ionized water to $100 \mathrm{ml}$ mark. The concentrations of chromium $(\mathrm{Cr})$, zinc $(\mathrm{Zn})$, cadmium $(\mathrm{Cd})$, and copper $(\mathrm{Cu})$ in the digested samples were determined using flame Atomic Absorption Spectrophotometer, AAS (PG Instrument, model: Pg-500, UK)) after calibrating the equipment with different standard concentrations. The calibration curves were prepared from standards by dissolving appropriate amounts of the metal salts in purified nitric acid, diluting with deionized water and storing as stock solutions in a quartz flask.

\subsection{Plant sampling and analysis of metals}

In this study, plant sampling for determination of heavy metals content in plants was carried out on individual plant species that had up to five (5) number of occurrence in each of the distances $(20,40$, 60 and $80 \mathrm{~m}$ ) at the sawdust waste dumpsite and control site. Fresh leaves were sampled from different shoots and parts of different plant species 4-5 years of age. The leaves of Eleusine indica L. (goose grass, Family-Poaceae), Sida rhombifolia L. (arrow leaf sida, Family- Malvaceae), Amaranthus spinosus L. (spiny amaranth, spiny pigweed or thorny amaranth, FamilyAmaranthaceae) and Centrosema pubescence Benth (centro, butterfly pea, Family- Fabaceae) were collected randomly in the month of August separately from each individual plant using well-cleaned secateurs at the various distances at the sawdust dumpsite $(20,40,60$ and $80 \mathrm{~m}$ ) and control site (a 5 year upland bush fallow that is $500 \mathrm{~m}$ from the dump site where there was no visible source of contamination). Three replicates of each plant species were collected and mixed separately to obtain composite samples. These samples were well labelled and transferred to the laboratory for pretreatment and analysis. The plant samples were cleaned sequentially with deionized water to remove dust, pollens and debris and oven dried at $60{ }^{\circ} \mathrm{C}$ for $72 \mathrm{hrs}$. Thereafter, the leaf samples from each separate plant species were milled with Thomas Wiley milling machine (Model ED-5 USA) to fine powder. The procedure described by Kakulu and Jacob (2006) but slightly modified was used for digestion of plant samples. A $5 \mathrm{ml}$ of $4: 1$ mixture of concentration of $\mathrm{HNO}_{3}: \mathrm{HCl}_{4}$ was added to $2 \mathrm{~g}$ of plant sample and the mixture was heated at $105{ }^{\circ} \mathrm{C}$ for an hour to dryness on a hot plate, allowed to cool and made up to the mark of $50 \mathrm{ml}$ volumetric flask with $1 \mathrm{M} \mathrm{HNO}_{3}$. The solution was centrifuge for 30 minutes and transferred to sampling bottle for analysis. Triplicate digestion of each sample was carried out and blanks were prepared from only reagents without sample to check for background contamination by the reagents. Appropriate quality assurance procedures and precautions were taken to ensure the reliability of the results. Samples were carefully handled to avoid cross-contamination. Glassware was properly cleaned, and reagents used were of analytical grades. Deionized water was used throughout the study. Working standard solutions of chromium $(\mathrm{Cr})$, zinc $(\mathrm{Zn})$, cadmium $(\mathrm{Cd})$, and copper $(\mathrm{Cu})$ were prepared from the stock standard solutions containing $1000 \mathrm{ppm}$ of element in $2 \mathrm{~N}$ nitric acid. Calibration and measurement of elements were done on flame Atomic Absorption 
Spectrophotometer, AAS (PG Instrument model: Pg-500, UK). A blank reading was also taken and necessary correction was made during the calculation of concentration of various elements.

\subsection{Experimental design and data analysis}

A 4 x 3 factorial experiment in Randomized Complete Block Design (RCBD) in three replicates in soil depth was used. Data collected from this study was subjected to 2-way Analysis of Variance (ANOVA) using Statistical Analysis System (SAS) version 9 to test the significance of difference in total mean concentration in sawdust, soil and plant samples and means separated using Duncan Multiple Range Test (DNMRT) at 0.05 probability level test. The correlation of heavy metals was analysed using Pearson correlation analysis.

\subsection{Results and Discussion}

\subsection{Metal concentration $(\mathrm{mg} / \mathrm{kg})$ in sawdust}

The values of the concentration of metals in samples of sawdust collected from the three (3) sawdust dumps is presented in Table 1. Sawdust concentrations of all metals were raised to different levels and the significant differences was evidenced amongst the three sawdust dumps at Ahiaeke. Wood processing at the timber market resulted to generation of metal contaminated sawdust that are dumped within the vicinity. The value for the highest concentration of $\mathrm{Zn}(51.00 \pm 1.84 \mathrm{mg} / \mathrm{kg})$ was recorded at sawdust dump 2 and the value is significantly $(\mathrm{P}<0.05)$ higher than values recorded for $\mathrm{Zn}$ at sawdust dump $3(44.83 \pm 0.3535 \mathrm{mg} / \mathrm{kg})$ and sawdust dump $1(41.06 \pm 0.226 \mathrm{mg} / \mathrm{kg})$. The metal analyses of sawdust particles revealed the following properties presented in Table 1. The high value of $\mathrm{Zn}$ at sawdust dump 2 suggest that the sawdust were generated from trees that grew on soil rich in $\mathrm{Zn}$. Plants growing on metal contaminated soil may take up metals from soils and translocate it to the stem.

Table 1: Metal concentration $(\mathrm{mg} / \mathrm{kg})$ in sawdust

\begin{tabular}{|l|l|l|l|l|}
\hline Sawdust dumpsite & $\mathrm{Zn}$ & $\mathrm{Cu}$ & $\mathrm{Cd}$ & $\mathrm{Cr}$ \\
\hline 1 & $41.06 \pm 0.226^{\mathrm{b}}$ & $8.24 \pm 0.6^{\mathrm{a}}$ & $3.715 \pm 0.219^{\mathrm{b}}$ & $0.084 \pm 0.0085^{\mathrm{b}}$ \\
\hline 2 & $51.00 \pm 1.84^{\mathrm{a}}$ & $6.84 \pm 0.37^{\mathrm{a}}$ & $3.895 \pm 0.4313^{\mathrm{b}}$ & $0.17 \pm 0.014^{\mathrm{a}}$ \\
\hline 3 & $44.83 \pm 0.3535^{\mathrm{b}}$ & $7.82 \pm 0.4^{\mathrm{a}}$ & $4.72 \pm 0.071^{\mathrm{a}}$ & $0.125 \pm 0.0071^{\mathrm{ba}}$ \\
\hline
\end{tabular}

Mean in the same column followed by the same letter are not significantly different $(p<0.05)$ according to DMRT Values are mean \pm standard deviation of 3 replications

It also suggests that the sawdust at the three dumps (i.e. 1, 2 and 3) were generated from trees that grew on different sites in the wild forest or exotic plantations thus, the differences in the values of $\mathrm{Zn}$ at the three sawdust dumps. The values of $\mathrm{Zn}$ in sawdust dumps at Ahiaeke timber market range from $41.06 \pm 0.226$ to $51.00 \pm 1.84 \mathrm{mg} / \mathrm{kg}$ which is higher than $3.54 \pm 0.28 \mathrm{mg} / \mathrm{kg}$ in pine wood briquette made from planer shavings and sawdust from high quality pure pine wood (Swietlik et al., 2014).

The value for the highest concentration of $\mathrm{Cu}(8.24 \pm 0.60 \mathrm{mg} / \mathrm{kg})$ was recorded at dump 1 but the value is statistically equal $(\mathrm{P}>0.05)$ to its corresponding values at sawdust dump $2(6.84 \pm 0.37$ $\mathrm{mg} / \mathrm{kg})$ and sawdust dump $3(7.82 \pm 0.40 \mathrm{mg} / \mathrm{kg})$. The values of $\mathrm{Cu}$ at the three dumps suggest that the sawdust were likely generated from trees harvested from the same sites (i.e. location) or sites with similar edaphic nature. The values of $\mathrm{Cu}$ in sawdust dumps range from $6.84 \pm 0.37$ to $8.24 \pm 0.60$ $\mathrm{mg} / \mathrm{kg}$ which is higher than $0.65 \pm 0.08 \mathrm{mg} / \mathrm{kg}$ in pine wood briquette made from planer shavings and sawdust from high quality pure pine wood (Swietlik et al., 2014).

The value for the highest concentration of Cd $(4.72 \pm 0.071 \mathrm{mg} / \mathrm{kg})$ was recorded at sawdust dump 3 and the value is significantly $(\mathrm{P}<0.05)$ higher than values of $\mathrm{Cd}$ at sawdust dump $1(3.715 \pm 0.219$ $\mathrm{mg} / \mathrm{kg})$ and sawdust dump $2(3.895 \pm 0.4313 \mathrm{mg} / \mathrm{kg})$. The high Cd at sawdust dump 3 is attributed to $\mathrm{Cd}$ assimilated by the trees (via the roots) while taken up macronutrients from soil solution. The $\mathrm{Cd}$ assimilated in such trees were released in form of sawdust particles while been processed at the Ahiaeke timber market and possibly disposed at sawdust dump 3. The values of $\mathrm{Cd}$ in sawdust dumps range from $3.715 \pm 0.219$ to $4.720 \pm 0.071 \mathrm{mg} / \mathrm{kg}$ which is higher than $0.50 \mathrm{mg} / \mathrm{kg}$ reported in sawdust particles in the vicinity of sawmill in Sapele, Nigeria (Nwajei and Iwegbue, 2007). 
The value for the highest concentration of $\mathrm{Cr}(0.170 \pm 0.014 \mathrm{mg} / \mathrm{kg})$ was obtained at sawdust dump 2 and the value is significantly $(\mathrm{P}<0.05)$ higher than value observed at sawdust dump $1(0.084 \pm$ $0.0085 \mathrm{mg} / \mathrm{kg}$ ) but statistically equal $(\mathrm{P}>0.05)$ to the value of $\mathrm{Cr}$ at sawdust dump $3(0.125 \pm 0.0071$ $\mathrm{mg} / \mathrm{kg}$ ).

The main source of $\mathrm{Zn}, \mathrm{Cu}$ and $\mathrm{Cr}$ in sawdust particles of Ahiaeke timber market are the chemicals used in pest and disease control in various man-made forest plantations. Pesticides such as copper sulphate, Boliden salt (BIS-salt) mixed with zinc sulphate and chromate copper arsenate (CCA) have been used for over five decades (Bahattacharya et al. 2002). The values of $\mathrm{Cr}$ in sawdust dumps range from $0.084 \pm 0.0085$ to $0.170 \pm 0.014 \mathrm{mg} / \mathrm{kg}$ which is well below 1.46 to $160.50 \mathrm{mg} / \mathrm{kg}$ in sawdust particles in the vicinity of sawmill in Sapele, Nigeria (Nwajei and Iwegbue, 2007). The values of $\mathrm{Cr}$ $(0.084 \pm 0.0085$ to $0.170 \pm 0.014 \mathrm{mg} / \mathrm{kg}), \mathrm{Cd}(3.715 \pm 0.219$ to $4.720 \pm 0.071 \mathrm{mg} / \mathrm{kg})$ and $\mathrm{Cu}(6.84 \pm$ 0.37 to $8.24 \pm 0.60 \mathrm{mg} / \mathrm{kg}$ ) in the three sawdust dumps at Ahiaeke timber market are well below the maximum permitted levels of $25 \mathrm{mg} / \mathrm{kg}(\mathrm{Cr}), 50 \mathrm{mg} / \mathrm{kg}(\mathrm{Cd})$ and $40 \mathrm{mg} / \mathrm{kg}(\mathrm{Cu})$ established by the Waste and Regeneration Action Program and the British Standard Institution (BSI, 2012). Thus, the sawdust is safe for panel board manufacturing. Similarly, the values of the metals are well below the maximum permitted levels of $100 \mathrm{mg} / \mathrm{kg}(\mathrm{Cr}), 200 \mathrm{mg} / \mathrm{kg}(\mathrm{Cu})$ and $400 \mathrm{mg} / \mathrm{kg}(\mathrm{Zn})$ except for Cd that is higher than $1.5 \mathrm{mg} / \mathrm{kg}$ (Cd) for porous surface application (BSI, 2012) of sawdust in soil. Notwithstanding this, persistent application of the sawdust for composting and mulching over time (i.e. years) can trigger the concentrations of the metals $(\mathrm{Cr}, \mathrm{Cd}, \mathrm{Zn}$ and $\mathrm{Cu})$ to and above the maximum permitted levels in agricultural lands. Generally, the concentration of the metals in sawdust particles followed a decreasing order: $\mathrm{Zn}>\mathrm{Cu}>\mathrm{Cd}>\mathrm{Cr}$.

\subsection{Metals concentration $(\mathrm{mg} / \mathrm{kg})$ in soil}

The values of the concentration of metals in different soil depths at the various distances at timber market sawdust dumpsite are presented in Table 2. The results show that the highest and lowest metal concentrations in soil were observed at the dumpsite and control site, respectively. Investigations on some pollution surveys showed that air, soil or plants adjoined to source of pollutants had elevated metal concentrations than the control area (Imperatoa et al., 2003; Moreno et al., 2003; Birch and Snowdon, 2004; Davila et al., 2006). Since there were no other sources of contamination in the area, the high concentrations of metals in soils of the sawdust dumpsite (unlike the control site) may be attributed to leaching of these metals $(\mathrm{Cd}, \mathrm{Zn}, \mathrm{Cu}$ and $\mathrm{Cr}$ ) from the mountainous sawdust waste. Ncube and Phiri (2015) reported presence of metals in Eucalyptus and Pinus wood sawdust and smoke in Copperbelt province, Zambia. Nwajei and Iwegbue (2007) also reported some heavy metals in sawdust particles in the vicinity of sawmill in Sapele, Nigeria. Consequently, sawdust can influence the natural concentrations of heavy metals in soil. Copper fungicides and other forms of pesticides used to control disease infection and pest infestation in exotic plantations (e.g. Gmelina arborea. Pinus caribea, Eucalyptus camadulensis, Tectona grandis among others) may have contributed to metal load in soil and subsequent accumulation in the trees. Mala et al. (2007) in their study of heavy metal uptake in plants reported heavy metals in the anatomical features of stem. From the study, it was observed that the values of metals decreased with soil depth at the timber market sawdust dumpsite.

The magnitude of decline in metals concentration with depth in this study varied amongst sampling distance $(20,40,60$ and $80 \mathrm{~m})$ and control area but the rate of decline were highest at the control area, followed by $80 \mathrm{~m}, 60 \mathrm{~m}, 40 \mathrm{~m}$, and lastly $20 \mathrm{~m}$. The high concentration of $\mathrm{Zn}, \mathrm{Cu}, \mathrm{Cd}$ and $\mathrm{Cr}$ in $0-10$ $\mathrm{cm}$ depth at various distances is attributed to organic materials on the surface soil. Metals are bound to topsoil by organic matter (Sukkariyah et al., 2005) because they (metals) are complexed, hence reducing the leaching of metals into the lower depths (i.e. $11-20$ and $21-30 \mathrm{~cm}$ ). It was also observed that the values of metals at the timber market sawdust dumpsite area decreased exponentially with distance. Such non-linear decreasing metal concentrations in soils with increasing distance to the emission source have been reported in a similar study (Escarré et al., 2010). This suggests that sawdust is the source of metals leached across the various distances where soil samples were tested in this study. Liang et al. (2003) opined that transfer through water runoff is the main vehicle of heavy metals transportation in soil. 
Table 2: Metals concentration $(\mathrm{mg} / \mathrm{kg})$ in soil samples

\begin{tabular}{|l|l|l|l|l|l|}
\hline $\begin{array}{l}\text { Distance } \\
(\mathrm{m})\end{array}$ & Depth (cm) & $\mathrm{Zn}$ & $\mathrm{Cu}$ & $\mathrm{Cd}$ & \\
\hline 20 & $0-10$ & $119.7 \pm 7.02^{a}$ & $75.85 \pm 4.8^{a}$ & $22.39 \pm 3.3^{a}$ & $0.8 \pm 0.07^{a}$ \\
& $11-20$ & $89.4 \pm 9.01^{b}$ & $53.63 \pm 2.3^{b}$ & $13.72 \pm 1.52^{c}$ & $0.55 \pm 0.47^{a b c}$ \\
& $21-30$ & $67.36 \pm 4.06^{c}$ & $36.67 \pm 2.96^{d}$ & $7.93 \pm 1.66^{e}$ & $0.27 \pm 0.05^{b c d}$ \\
\hline 40 & $0-10$ & $82.01 \pm 7.97^{b}$ & $48.36 \pm 3.34^{c}$ & $16.90 \pm 1.94^{b}$ & $0.641 \pm 0.03^{a b}$ \\
& $11-20$ & $70.42 \pm 6.24^{c}$ & $31.27 \pm 1.15^{e}$ & $10.62 \pm 1.14^{d}$ & $0.35 \pm 0.03^{b c d}$ \\
& $21-30$ & $56.99 \pm 9.00^{d}$ & $21.92 \pm 1.95^{f}$ & $4.95 \pm 4.0 .71^{g}$ & $0.19 \pm 0.03^{b c d}$ \\
\hline 60 & $0-10$ & $63.42 . \pm 7.82^{c d}$ & $31.18 \pm 1.19^{e}$ & $11.55 \pm 1.59^{d}$ & $0.39 \pm 0.03^{a b c}$ \\
& $11-20$ & $56.16 \pm 8.61^{c d}$ & $23.74 \pm 4.39^{f}$ & $6.27 \pm 1.17^{f}$ & $0.22 \pm 0.05^{b c d}$ \\
& $21-30$ & $39.1 \pm 9.42^{e}$ & $18.36 \pm 2.99^{g}$ & $3.15 \pm 1.35^{h}$ & $0.12 \pm 0.04^{c d}$ \\
\hline 80 & $0-10$ & $49.56 \pm 5.14^{d}$ & $22.96 \pm 1.64^{f}$ & $4.76 \pm 0.36^{g}$ & $0.15 \pm 0.03^{c d}$ \\
& $11-20$ & $35.48 \pm 11.78^{e}$ & $17.37 \pm 1.09^{g}$ & $1.35 \pm 0.47^{i}$ & $0.09 \pm 0.03^{d}$ \\
& $21-30$ & $25.49 \pm 7.35^{f e}$ & $11.86 \pm 0.81^{h}$ & $0.48 \pm 0.16^{i}$ & $0.05 \pm 0.03^{d}$ \\
\hline Control & $0-10$ & $31.26 \pm 3.23^{e}$ & $18.18 \pm 2.27^{g}$ & $0.29 \pm 0.11^{i j}$ & $0.01 \pm 0.01^{d}$ \\
& $11-20$ & $19.08 \pm 2.94^{f}$ & $11.06 \pm 1.40^{h}$ & $0.11 \pm 0.05^{i j}$ & $0.00 \pm 0.00^{d}$ \\
& $21-30$ & $10.11 \pm 0.97^{g f}$ & $6.80 \pm 1.59^{i}$ & $0.02 \pm 0.02^{j}$ & $0.00 \pm 0.00^{d}$ \\
\hline
\end{tabular}

Mean in the same column followed by the same letter are not significantly different $(p<0.05)$ according to DMRT

Values are mean \pm standard deviation of 3 replications

The concentration of $\mathrm{Zn}(119.7 \pm 7.02 \mathrm{mg} / \mathrm{kg}), \mathrm{Cu}(75.85 \pm 4.80 \mathrm{mg} / \mathrm{kg})$ and $\mathrm{Cd}(22.39 \pm 3.30 \mathrm{mg} / \mathrm{kg})$ in $0-10 \mathrm{~cm}$ at a distance of $20 \mathrm{~m}$ to the timber market sawdust dumpsite is significantly $(\mathrm{P}<0.05)$ higher than their corresponding values at $40 \mathrm{~m}(82.01 \pm 7.97,48.36 \pm 3.34$ and $16.90 \pm 1.94 \mathrm{mg} / \mathrm{kg})$, $60 \mathrm{~m}(63.42 \pm 7.82,31.18 \pm 1.19$ and $11.55 \pm 1.59 \mathrm{mg} / \mathrm{kg}), 80 \mathrm{~m}(49.56 \pm 5.14,22.96 \pm 1.64$ and 4.76 $\pm 0.36 \mathrm{mg} / \mathrm{kg})$ and control $(31.26 \pm 3.23,18.18 \pm 2.27$ and $0.29 \pm 0.11 \mathrm{mg} / \mathrm{kg})$. The metals present in the timber market sawdust dumpsite may have provided a source for continued dispersion down the distance, and have resulted to various degree of contamination in soils. The concentrations of $\mathrm{Zn}, \mathrm{Cu}$ and $\mathrm{Cd}$ in $0-10 \mathrm{~cm}$ depth at a distance of $20 \mathrm{~m}$ were found to be $1.46,1.57$ and 1.32 times higher than their values in $0-10 \mathrm{~cm}$ at $40 \mathrm{~m} ; 1.89,2.43$ and 1.94 times higher than their values at $60 \mathrm{~m}$; 2.42, 3.30 and 4.70 times higher than their values at $80 \mathrm{~m}$; and 3.83, 4.17 and 77.21 times higher than their values at the control area, respectively for $\mathrm{Zn}, \mathrm{Cu}$ and $\mathrm{Cd}$. The concentration of these metals at the study area is well above their concentrations at the control area. Logan and Miller (1983) suggested that soil is contaminated when concentrations of metals in soils were two-to-three times higher than the control. In this study, the concentrations of $\mathrm{Zn}, \mathrm{Cu}$ and $\mathrm{Cd}$ were more than three times higher than their concentrations at the control area. Therefore, the soil at the timber market sawdust dumpsite area can be said to be contaminated based on the findings that $\mathrm{Zn}, \mathrm{Cu}$ and $\mathrm{Cd}$ concentrations in the control soil samples were well below their corresponding values at the study area.

The values of the concentration of $\mathrm{Zn}, \mathrm{Cu}$ and $\mathrm{Cd}$ in timber market soils of Ahiaeke, Abia State, Nigeria were $25.49 \pm 7.35$ to $119.7 \pm 7.02,11.86 \pm 0.81$ to $75.85 \pm 4.80$ and $0.48 \pm 0.16$ to $22.39 \pm$ $3.30 \mathrm{mg} / \mathrm{kg}$, respectively for $\mathrm{Zn}, \mathrm{Cu}$ and $\mathrm{Cd}$, which are above the maximum permitted levels of 60 $\mathrm{mg} / \mathrm{kg}(\mathrm{Zn})$ and $0.1 \mathrm{mg} / \mathrm{kg}(\mathrm{Cd})$ established by the Codex Alimentarius Commission (FAO/WHO, 2001) (Table 3). Similarly, the concentrations of $\mathrm{Cu}(11.86 \pm 0.81$ to $75.85 \pm 4.80 \mathrm{mg} / \mathrm{kg})$ and $\mathrm{Cd}$ $(0.48 \pm 0.16$ to $22.39 \pm 3.30 \mathrm{mg} / \mathrm{kg})$ in soils at the timber market sawdust dumpsite area is above the accepted limits (i.e. target value) of $36 \mathrm{mg} / \mathrm{kg}(\mathrm{Cu})$ and $0.8 \mathrm{mg} / \mathrm{kg}(\mathrm{Cd})$ as described by Dutch criteria for soil (Wikipedia, 2013).

Table 3: Comparison of results with International Standard (Dutch Criteria and FAO/WHO Codex Alimentarius Commission

\begin{tabular}{|l|l|l|l|}
\hline & $\begin{array}{l}\text { Dutch criteria } \\
\text { (target value) } \mathrm{mg} / \mathrm{kg}\end{array}$ & $\begin{array}{l}\text { FAO/WHO 2001 } \\
\text { Codex Alimentarius Commission }(\mathrm{mg} / \mathrm{kg})\end{array}$ & $\begin{array}{l}\text { NESREA 2011 } \\
\text { Standard (mg/kg) }\end{array}$ \\
\hline $\mathrm{Zn}$ & 140 & 60 & 421 \\
\hline $\mathrm{Cu}$ & 36 & 100 & 100 \\
\hline $\mathrm{Cd}$ & 0.8 & 0.1 & 3 \\
\hline $\mathrm{Cr}$ & 100 & 100 & 100 \\
\hline
\end{tabular}

The highest concentration of $\mathrm{Cr}(0.80 \pm 0.07 \mathrm{mg} / \mathrm{kg})$ in $0-10 \mathrm{~cm}$ depth at $20 \mathrm{~m}$ is statistically equal $(\mathrm{P}>0.05)$ with the values recorded in $0-10 \mathrm{~cm}$ depth at $40 \mathrm{~m}(0.641 \pm 0.03 \mathrm{mg} / \mathrm{kg})$ and $60 \mathrm{~m}(0.39 \pm$ $0.03 \mathrm{mg} / \mathrm{kg}$ ) but significantly $(\mathrm{P}<0.05)$ higher than $0.15 \pm 0.03 \mathrm{mg} / \mathrm{kg}$ at $80 \mathrm{~m}$ and $0.01 \pm 0.01 \mathrm{mg} / \mathrm{kg}$ 
at control area. The values of $\mathrm{Cr}(0.05 \pm 0.03$ to $0.80 \pm 0.07 \mathrm{mg} / \mathrm{kg})$ is well below the permitted limit of $100 \mathrm{mg} / \mathrm{kg}$ (Cr) established by the Codex Alimentarius Commission (FAO/WHO, 2001) (Table 3) and Dutch criteria for soil (Wikipedia, 2013). The values of $\mathrm{Zn}$ is $25.49 \pm 7.35$ to $119.7 \pm 7.02 \mathrm{mg} / \mathrm{kg}$ at the timber market sawdust dumpsite area, which is well above 3.58 to $9.19 \mathrm{mg} / \mathrm{kg}$ for $\mathrm{Zn}$ in soils at sawmills in Ekiti State, Nigeria (Ezekiel et al., 2013). The values of $\mathrm{Cu}(11.86 \pm 0.81$ to $75.85 \pm 4.80$ $\mathrm{mg} / \mathrm{kg}$ ) in this study are higher than 0.76 to $3.54 \mathrm{mg} / \mathrm{kg}$ (Ezekiel et al., 2013) in a similar study. Similarly, the value of $\mathrm{Cd}(0.48 \pm 0.16$ to $22.39 \pm 3.30 \mathrm{mg} / \mathrm{kg})$ is higher than 0.07 to $0.47 \mathrm{mg} / \mathrm{kg}$ reported by Ezekiel et al. (2013) but the values of $\mathrm{Cr}(0.05 \pm 0.03$ to $0.80 \pm 0.07 \mathrm{mg} / \mathrm{kg})$ in this study is well below 0.68 to $3.34 \mathrm{mg} / \mathrm{kg}$ for $\mathrm{Cr}$ in soils at sawmills in Ekiti State (Ezekiel et al., 2013). Generally, the values of the concentrations of metals in soil followed an increasing order: $\mathrm{Cr}<\mathrm{Cd}<$ $\mathrm{Cu}<\mathrm{Zn}$.

\subsection{Metals concentration $(\mathrm{mg} / \mathrm{kg})$ in plants}

The values of the concentration of metals tested in plant samples in this study are summarized in Table 4. The result indicates that the highest and lowest values of the concentration of metals were observed at the sawdust dumpsite and control site, respectively. The table shows that the plant species assimilated different levels of concentration of metals at various distances from the emission source (i.e. sawdust dumps). The result clearly indicate that Centrosema pubescence assimilated the highest values of $\mathrm{Zn}(34.70 \pm 7.05 \mathrm{mg} / \mathrm{kg}), \mathrm{Cu}(5.34 \pm 0.11 \mathrm{mg} / \mathrm{kg})$ and $\mathrm{Cd}(2.94 \pm 0.515 \mathrm{mg} / \mathrm{kg})$ but the values are statistically equal $(\mathrm{P}>0.05)$ to the values of $\mathrm{Zn}, \mathrm{Cu}$ and $\mathrm{Cd}$ in Eleusine indica $(30.90 \pm$ $7.70,4.87 \pm 1.20$ and $2.92 \pm 0.60 \mathrm{mg} / \mathrm{kg}$ ) and $28.50 \pm 6.74 \mathrm{mg} / \mathrm{kg} \mathrm{Zn}$ in Amaranthus spinosus but significantly $(\mathrm{P}<0.05)$ higher than values of $\mathrm{Zn}, \mathrm{Cu}$ and $\mathrm{Cd}$, respectively for Eleusine indica, Sida rhombifolia, Amaranthus spinosus and Centrosema pubescence at $40 \mathrm{~m}(22.07 \pm 5.93,3.106 \pm 0.23$ and $1.80 \pm 0.28 \mathrm{mg} / \mathrm{kg} ; 15.51 \pm 7.30,2.16 \pm 0.73$ and $1.04 \pm 0.575 \mathrm{mg} / \mathrm{kg} ; 16.25 \pm 5.46,1.90 \pm 0.20$ and $1.06 \pm 0.46 \mathrm{mg} / \mathrm{kg}$; and $23.79 \pm 4.01,3.70 \pm 0.337$ and $1.78 \pm 0.44 \mathrm{mg} / \mathrm{kg}), 60 \mathrm{~m}(10.11 \pm 3.14$, $2.183 \pm 0.30$ and $1.05 \pm 0.11 \mathrm{mg} / \mathrm{kg} ; 7.75 \pm 6.58,1.14 \pm 0.30$ and $0.51 \pm 0.11 \mathrm{mg} / \mathrm{kg} ; 7.05 \pm 8.032$, $1.47 \pm 0.13$ and $0.82 \pm 0.09 \mathrm{mg} / \mathrm{kg}$; and $10.89 \pm 2.73,2.39 \pm 0.45$ and $1.13 \pm 0.072 \mathrm{mg} / \mathrm{kg}), 80 \mathrm{~m}$ $(3.49 \pm 1.70,1.10 \pm 0.98$ and $0.577 \pm 0.04 \mathrm{mg} / \mathrm{kg} ; 2.30 \pm 1.10,0.903 \pm 0.12$ and $0.45 \pm 0.19 \mathrm{mg} / \mathrm{kg}$; $2.63 \pm 0.16,0.95 \pm 0.63$ and $0.413 \pm 0.071$; and $3.67 \pm 2.00,1.13 \pm 0.14$ and $0.52 \pm 0.01 \mathrm{mg} / \mathrm{kg}$ ) and the control $(1.17 \pm 0.54,0.23 \pm 0.095$ and $0.010 \pm 0.11 ; 0.61 \pm 0.95,0.096 \pm 0.08$ and $0.021 \pm 0.003$ $\mathrm{mg} / \mathrm{kg} ; 0.49 \pm 0.06,0.22 \pm 0.078$ and $0.013 \pm 0.0013 \mathrm{mg} / \mathrm{kg}$; and $1.540 \pm 0.71,0.38 \pm 0.10$ and 0.020 $\pm 0.005 \mathrm{mg} / \mathrm{kg}$ ). The high values of $\mathrm{Zn}, \mathrm{Cu}$ and $\mathrm{Cd}$ in $C$. pubescence may be attributed to the inherent ability of the plant (C. pubescence) to absorb and translocate more $\mathrm{Zn}, \mathrm{Cu}$ and $\mathrm{Cd}$ to the aerial plant parts (leaves) than other plant species. Its deep root system (Wikipedia, 2018) might have facilitated the absorption of the metals in soil solution from a significant depths and translocation to the aerial part of the plant. Metal accumulation in plants is dependent on type of metal and plant species involved (Juste and Mench, 1992; Ogbonna and Okezie, 2011).

The value of the concentration of $\mathrm{Zn}$ increased from $2.30 \pm 1.10 \mathrm{mg} / \mathrm{kg}$ (S. rhombifolia) at $80 \mathrm{~m}$ to $34.70 \pm 7.05 \mathrm{mg} / \mathrm{kg}$ (C. pubescence) at $20 \mathrm{~m}$. The level of $\mathrm{Zn}$ in this study is below the permissible limit (PL) of $50 \mathrm{mg} / \mathrm{kg}$ set by Codex Alimentarius Commission, FAO/WHO (2006) for vegetables and herbs. The value of $\mathrm{Zn}$ in C. pubescence at $20 \mathrm{~m}$ is 22.53 times higher than the highest value of $\mathrm{Zn}$ in plant at the control site. The value of the concentration of $\mathrm{Cu}$ increased from $0.903 \pm 0.12 \mathrm{mg} / \mathrm{kg}(S$. rhombifolia) at $80 \mathrm{~m}$ to $5.345 \pm 0.11 \mathrm{mg} / \mathrm{kg}$ (C. pubescence) at $20 \mathrm{~m}$. The level of $\mathrm{Cu}$ is lower than the permissible limit (PL) of $40 \mathrm{mg} / \mathrm{kg}$ set by FAO/WHO (2006) for vegetables and herbs. The value of $\mathrm{Cu}$ in $C$. pubescence at $20 \mathrm{~m}$ is 14.07 times higher than the highest value of $\mathrm{Cu}$ in plant at the control site. The value of the concentration of Cr increased from $0.0037 \pm 0.0055 \mathrm{mg} / \mathrm{kg}$ (C. pubescence) at $80 \mathrm{~m}$ to $0.132 \pm 0.01 \mathrm{mg} / \mathrm{kg}$ (C. pubescence) at $40 \mathrm{~m}$. The level of $\mathrm{Cr}$ is lower than the permissible limit (PL) of $2.3 \mathrm{mg} / \mathrm{kg}$ set by FAO/WHO (2006) for vegetable and herbs. The value of $\mathrm{Cr}$ in $C$. pubescence at $40 \mathrm{~m}$ is 0.132 times higher than the highest value of $\mathrm{Cr}$ in plant at the control site. The value of the concentration of Cd increased from $0.413 \pm 0.071$ (S. rhombifolia) at $80 \mathrm{~m}$ to $2.94 \pm$ $0.515 \mathrm{mg} / \mathrm{kg}$ (C. pubescence) at $20 \mathrm{~m}$. The level of $\mathrm{Cd}$ in this study is well above the permissible limit (PL) of $0.3 \mathrm{mg} / \mathrm{kg}$ set by FAO/WHO (2006) for vegetables and herbs. Consequently, the use of $C$. pubescence at the timber market for forage and source of protein for grazing animals can be a route of entry of metal $(\mathrm{Cd})$ in herbivores and subsequent bio-magnification of $\mathrm{Cd}$ in people that consume such metal contaminated animals. In furtherance to this, collection of planting material for growing as cover crops from such $\mathrm{Cd}$ contaminated $C$. pubescence will hamper soil fertility and health of soil 
organism such as earthworm. The value of $\mathrm{Cd}$ in $C$. pubescence at $20 \mathrm{~m}$ is 140 times higher than the highest value of Cd in plant at the control site. According to FAO (1991), sawmill wastes contain significant spectrum of organic substances capable of affecting the physical, chemical and biotic environment. Consequently, consumption of plants, animals or water contaminated with such substances can be deleterious to human health. Generally, the values of the concentration of metals followed an increasing order: $\mathrm{Cr}<\mathrm{Cd}<\mathrm{Cu}<\mathrm{Zn}$.

Table 4: Metals concentration $(\mathrm{mg} / \mathrm{kg})$ in plant samples

\begin{tabular}{|c|c|c|c|c|c|}
\hline Distance $(m)$ & Plant species & Zinc & $\mathrm{Cu}$ & $\mathrm{Cd}$ & $\mathrm{Cr}$ \\
\hline 20 & $\begin{array}{l}\text { E. indica } \\
\text { S. rhombifolla } \\
\text { A. Spinosus } \\
\text { C.pubescen }\end{array}$ & $\begin{array}{l}30.9 \pm 7.70^{\mathrm{a}} \\
23.9 \pm 6.35^{\mathrm{b}} \\
28.5 \pm 6.74^{\mathrm{ab}} \\
34.7 \pm 7.05^{\mathrm{a}}\end{array}$ & $\begin{array}{l}4.87 \pm 1.20^{\mathrm{a}} \\
3.173 \pm 0.68^{\mathrm{bc}} \\
3.57 \pm 1.35^{\mathrm{b}} \\
5.345 \pm 0.11^{\mathrm{a}}\end{array}$ & $\begin{array}{l}2.92 \pm 0.60^{\mathrm{a}} \\
1.89 \pm 0.42^{\mathrm{c}} \\
2.3 \pm 0.41^{\mathrm{bc}} \\
2.94 \pm 0.515^{\mathrm{a}}\end{array}$ & $\begin{array}{l}0.05 \pm 0.009^{\mathrm{b}} \\
0.04 \pm 0.007^{\mathrm{b}} \\
0.039 \pm 0.021^{\mathrm{b}} \\
0.037 \pm 0.18^{\mathrm{b}}\end{array}$ \\
\hline 40 & $\begin{array}{l}\text { E. indica } \\
\text { S. rhombifolla } \\
\text { A. Spinosus } \\
\text { C.pubescen }\end{array}$ & $\begin{array}{l}22.07 \pm 5.93^{\mathrm{bc}} \\
15.51 \pm 7.3^{\mathrm{cd}} \\
16.25 \pm 5.46^{\mathrm{cd}} \\
23.79 \pm 4.01^{\mathrm{b}}\end{array}$ & $\begin{array}{l}3.016 \pm 0.23^{\mathrm{bc}} \\
2.16 \pm 073^{\mathrm{d}} \\
1.9 \pm 0.20^{\mathrm{d}} \\
3.7 \pm 0.337^{\mathrm{b}}\end{array}$ & $\begin{array}{l}1.8 \pm 0.28^{\mathrm{c}} \\
1.04 \pm 0.575^{\mathrm{d}} \\
1.06 \pm 0.46^{\mathrm{d}} \\
1.78 \pm 0.44^{\mathrm{c}}\end{array}$ & $\begin{array}{l}0.0243 \pm 0.005^{\mathrm{b}} \\
0.0273 \pm 0.01^{\mathrm{b}} \\
0.05 \pm 0.04^{\mathrm{b}} \\
0.132 \pm 0.013^{\mathrm{a}}\end{array}$ \\
\hline 60 & $\begin{array}{l}\text { E. indica } \\
\text { S. rhombifolla } \\
\text { A. Spinosus } \\
\text { C.pubescen }\end{array}$ & $\begin{array}{l}10.11 \pm 3.14^{\mathrm{de}} \\
7.75 \pm 6.58^{\text {ef }} \\
7.05 \pm 8.032^{\mathrm{ef}} \\
10.89 \pm 2.73^{\mathrm{de}}\end{array}$ & $\begin{array}{l}2.183 \pm 0.3^{\mathrm{d}} \\
1.14 \pm 0.3^{\mathrm{e}} \\
1.47 \pm 0.13^{\mathrm{de}} \\
2.39 \pm 0.45^{\mathrm{c}}\end{array}$ & $\begin{array}{l}1.05 \pm 0.11^{\mathrm{d}} \\
0.51 \pm 0.11^{\mathrm{def}} \\
0.82 \pm 0.09^{\mathrm{de}} \\
1.13 \pm 0.072^{\mathrm{d}}\end{array}$ & $\begin{array}{l}0.044 \pm 0.048^{\mathrm{b}} \\
0.054 \pm 0.059^{\mathrm{b}} \\
0.037 \pm 0.037^{\mathrm{b}} \\
0.043 \pm 0.04^{\mathrm{b}}\end{array}$ \\
\hline 80 & $\begin{array}{l}\text { E. indica } \\
\text { S. rhombifolla } \\
\text { A. Spinosus } \\
\text { C.pubescen }\end{array}$ & $\begin{array}{l}3.49 \pm 1.70^{\mathrm{fg}} \\
2.3 \pm 1.10^{\mathrm{fg}} \\
2.63 \pm 0.16^{\mathrm{fg}} \\
3.67 \pm 2.00^{\mathrm{fg}}\end{array}$ & $\begin{array}{l}1.10 \pm 0.98^{\mathrm{ef}} \\
0.903 \pm 0.12^{\mathrm{ef}} \\
0.95 \pm 0.63^{\mathrm{ef}} \\
1.13 \pm 0.14^{\mathrm{e}}\end{array}$ & $\begin{array}{l}0.577 \pm 0.04^{\mathrm{def}} \\
0.45 \pm 0.19^{\mathrm{ef}} \\
0.413 \pm 0.071^{\mathrm{ef}} \\
0.52 \pm 0.01^{\mathrm{def}}\end{array}$ & $\begin{array}{l}0.007 \pm 0.05^{\mathrm{b}} \\
0.004 \pm 0.06^{\mathrm{b}} \\
0.0071 \pm 0.0051^{\mathrm{b}} \\
0.0037 \pm 0.0055^{\mathrm{b}}\end{array}$ \\
\hline Control & $\begin{array}{l}\text { E. indica } \\
\text { S. rhombifolla } \\
\text { A. Spinosus } \\
\text { C.pubescen }\end{array}$ & $\begin{array}{l}1.17 \pm 0.54^{\mathrm{fg}} \\
0.61 \pm 0.95^{\mathrm{g}} \\
0.49 \pm 0.06^{\mathrm{g}} \\
1.540 \pm 0.71^{\mathrm{g}}\end{array}$ & $\begin{array}{l}0.23 \pm 0.095^{\mathrm{fg}} \\
0.096 \pm 0.085^{\mathrm{g}} \\
0.22 \pm 0.078^{\mathrm{fg}} \\
0.38 \pm 0.10^{\mathrm{fg}}\end{array}$ & $\begin{array}{l}0.010 \pm 0.11^{\mathrm{f}} \\
0.021 \pm 0.003^{\mathrm{f}} \\
0.013 \pm 0.0013^{\mathrm{f}} \\
0.020 \pm 0.005^{\mathrm{f}}\end{array}$ & $\begin{array}{l}\text { ND } \\
\text { ND } \\
\text { ND } \\
\text { ND }\end{array}$ \\
\hline
\end{tabular}

Mean in the same column followed by the same letter are not significantly different ( $p<0.05)$ according to DMRT Values are mean \pm standard deviation of 3 replications

\subsection{Conclusion}

The results of this work showed that sawdust particles at Umuahia timber market contain $\mathrm{Zn}, \mathrm{Cr}, \mathrm{Cu}$ and $\mathrm{Cd}$ and their concentration are within the safe limit. It was discovered that the sawdust is safe for mulching and production of wood panels. The highest concentration of metals occurred at the surface soil and the levels of $\mathrm{Zn}$ and $\mathrm{Cd}$ exceeded the permissible limit set by Codex Alimentarius Commission and Dutch criteria for soil. Similarly, the value of the concentration of $\mathrm{Cd}$ in Centrosema pubescence exceeded the permissible limit established by the Codex Alimentarius Commission. Thus, the $C$. pubescence can be used for phytoremediation of the metal contaminated site only on the condition that it will not be fed to animals or used for medicinal purposes by man.

\section{Acknowledgement}

The authors wish to acknowledge the laboratory staff of National Root Crops Research Institute, Umudike, Abia State toward the success of this work.

\section{References}

Amusan, A.A., et al. (2005). Characteristics of soils and crops uptake of metals in municipal waste dumpsites in Nigeria. Journal of Human Ecology, 17(3), pp. 167-171.

Arimoro, F.O., et al. (2007). The impact of sawmill wood wastes on the water quality and fish communities of Benin river, Niger Delta area, Nigeria. World Journal of Zoology, 1(2), pp. 94-102.

Bahattacharya, P., et al. (2002). Metal concentration at a wood preservation site: Characterization and experimental studies on remediation. Science Total Environment, 290, pp. 165-180.

Bello, R.S. and Mijinyawa, Y., (2010). Assessment of injuries in small scale sawmill industry of south western Nigeria. Journal of Scientific Research and Development, Manuscript 1558. XII. 
Birch, G.F. and Snowdon A., (2004). The nature and distribution of copper, lead, and zinc in soils of a highly urbanized sub-catchment (iron Cove) of Port Jackson, Sydney. Australian Journal of Soil Research, 42(3), pp. 329-338.

Boateng, C.A. and Amefodu, G.K., (2004). Industrial noise pollution and its effects on the hearing capabilities of workers. African Journal of Health Sciences, 11, pp. 1-2.

British Standard Institution, BSI (2012). Specification for the requirements and test methods for processing waste wood. Publicly Available Specification, London.

Chapel, A., (1986). Foliar fertilization In: Alexander A. (ed) Martinus Nijhoff, Dordrecht, pp. 66-86.

Davies, B.E., (1983). A graphical estimation of the normal lead content of some British soils. Geoderm, 29, pp. 67-75.

Davila, A.F., et al. (2006). Mapping the sources of urban dust in a coastal environment by measuring magnetic parameters of Plantanus hispanic leaves. Environmental Science and Technology, 40(12), pp. 3922-3928.

Edith, C.P. and Nkwocha, E.E., (2012). Assessment of the impact of sawmill industry on ambient air quality at Utu community in Akwa-Ibom State Nigeria. International Journal of Science and Nature, 3(1), pp. 205-211.

Escarre, J., Lefebvre, C., Raboyeau, S., dos Santos, A., Gruber, W., et al. (2010). Heavy metal concentration survey in soils and plants of the les Malines mining district (Southern France): implications for soil restoration. Water Air Soil Pollution, 216, pp. 485-504.

Ezekiel, A.K., et al. (2013). Determination of Heavy Metals in Soil Samples of Selected Sawmills in Ekiti State, Nigeria. Journal of Scientific Research and Reports 2(2), pp. 513-521.

FAO (1991). African fisheries and the Environment FAO Regional Office, Accra, RAFR/91/02, Accra, Ghana, pp. 26.

Finkelman R.B., (2007). Health impacts of coal: facts and fallacies. Royal Swedish Academy of Sciences. Ambio, 36, pp. 103-105.

Imperatoa, M., Adamo, P., Naimo, D., Arienzo, M., Stanzione, D., et al. (2003). Spatial distribution of heavy metals in urban soils of Naples city (Italy). Environmental Pollution, 124, pp. 247-256.

Juste, C. and Mench, M., (1992). Long term application of sewage and its effect on metal uptake by crops, pp. 159-194 in Biogeochemistry of trace metals, edited by D. C. Adriano. CRC Press, Boca Raton.

Kabata-Pendias, A., (2001). Trace elements in soils and plants, CRC Press, Boca Raton.

Kakulu S.E. and Jacob, J.O., (2006). Comparison of digestion methods for trace metal determination in moss samples. In: Proceedings of the $1^{\text {st }}$ National Conference of the Faculty of Science, University of Abuja, pp. 77-81.

Keay, R.W.J., (1959). An outlines of Nigeria vegetation, Government Printer, Lagos, Nigeria.

Lasode, O.A. and Balogun, O.A., (2010) Wood waste generation in Ilorin metropolis: Problems, management and prospects. In: Proceedings of the 25th International Conference on Solid Waste Technology and Management at Philadelphia, USA, March 14-17, March, 2010.

Liang, T., et al. (2003). Transportation processes and rates of heavy metals in an artificial rainstorm runoff under different land use types. Chinese Journal of Applied Ecology, 14, pp. 1756-1760. 
Logan, T.J. and Miller, R.H., (1983). Background levels of heavy metals in Ohio farm soil. Research Circular, 275, pp. 3-15.

Mala, J., et al. (2007). Heavy metals uptake by the hybrid aspen and rowan-tree clones. Journal of Forest Science, 53, pp. 491-497.

Mathew, B.B., et al. (2014). Toxicity, mechanism and health effects of some heavy metals. Interdisciplinary Toxicology, 7(2), pp. 60-72.

Moreno, J.L., et al. (2003). Toxic effect of cadmium and nickel on soil enzymes and the influence of adding sewage sludge. Eurasian Journal of Soil Science, 54(2), pp. 377-386.

Ncube, E. and Phiri, B., (2015). Concentrations of heavy metals in Eucalyptus and Pinus wood sawdust and smoke, Copperbelt Province, Zambia. Maderas Ciencia y Tecnologia, 17(3), pp. 585596.

NESREA, 2011. “1 ${ }^{\text {st }}$ Eleven Gazetted Regulations Federal Republic of Nigeria Official Gazette.”

Nwajei, G.E. and Iwegbue, C.M.A., (2007). Trace elements in sawdust particles in the vicinity of sawmill in Sapele, Nigeria. Pakistan Journal of Biological Sciences 10, pp. 4311-4314.

Ogbonna, P.C. and Nzegbule, E.C., (2009). Quantity and quality of litterfall in pure Gmelina arborea and pure Pinus caribea plantations in Umuahia, Abia State. Proceedings of the $33^{\text {rd }}$ Annual Conference of the Forestry Association of Nigeria held in Benin City, Edo State, Nigeria, 25-29 October, 2009, pp. 181-188.

Ogbonna, P.C. and Okezie, N., (2011). Heavy metal and macronutrient content of roadside soil and vegetation in Umuahia, Nigeria. Journal of Terrestrial and Aquatic Environmental Toxicology, 5(1), pp. 35-39.

Oke, S.O. and Oyedare, P.F., (2006). Effect of sawmilling activities on vegetation characteristics in Isokan area of southwestern Nigeria. Department of Botany, Institute of Ecology and Environmental Studies, Obafemi Awolowo University, Ile-Ife, Nigeria.

Pitchell, J. and Anderson, M., (1997). Trace metal bioavailability in municipal solid waste and sewage sludge composts. Bioresource Technology, 60, pp.223-229.

Plunkett, E.R., (1987). Handbook of industrial toxicology. Edward Arnold Chemical Publishing Co. Inc. USA, pp. 148-151.

Sukkariyah, B.F., et al. (2005). Recovery and distribution of biosolids-derived trace metals in a clay loam soil. Journal of Environmental Quality, 34(5), pp. 1843-1850.

Swietlik, R., et al. (2014). Distribution patterns of $\mathrm{Cd}, \mathrm{Cu}, \mathrm{Mn}, \mathrm{Pb}$ and $\mathrm{Zn}$ in wood fly ash emitted from domestic boilers. Chemical Speciation and Bioavailability, 25(1), pp. 63-70.

Ugheoke, A.J., et al. (2006). Influence of smoking on respiratory symptoms and lung function indices in sawmill workers in Benin City, Nigeria. Nigerian Journal of Physiological Sciences, 21(1-2), pp. 49-54.

Verma D.K., et al. (2007) Occupational Exposure to Chemical, Biological, and Physical Agents in Ontario Sawmill and Veneer/Plywood Plants. Program in Occupational Health and Environmental Medicine and Occupational and Environmental Health Laboratory, McMaster University, 1200 Main Street West, Hamilton, Ontario L8N 3Z5.

Wikipedia (2013). Dutch Standards for heavy metals in soil [Online], Available from: www.en.wikipedia.org/wiki/Dutch standards. [accessed 28 May 2013]. 
Wikipedia (2018). Centrosema pubescens https://en.wikipedia.org/wiki/Centrosema pubescens. Accessed 30 ${ }^{\text {th }}$ August, 2018.

World Health Organization, FAO/WHO (2001). Managing water in the home: Accelerated health gains from improved water supply, Geneva.

World Health Organization, FAO/WHO (2006). Guidelines for Assessing Quality of Herbal Medicines with Reference to Contaminants and Residues, World Health Organization, Geneva, Switzerland.

Wu, C. and Zhang, L., (2010). Heavy metal concentrations and their possible sources in paddy soils of a modern agriculture zone, south-eastern China. Environmental Earth Sciences 60, pp. 45-56. 